Office of Naval Research

Department of the Navy

Contract Nonr 220(43)

\title{
MEASUREMENTS OF THE WATER SURFACE \\ CONTOUR BEHIND A HYDROFOIL \\ OF MODERATE ASPECT RATIO
}

by

J. Brentjes

Hydrodynamics Laboratory

Kármán Laboratory of Fluid Mechanics and Jet Propulsion

California Institute of Technology

Pasadena, California

Report No. E-110.4

February 1964 


\author{
Department of the Navy \\ Office of Naval Research \\ Contract Nonr 220(43)
}

\title{
MEASUREMENTS OF THE WATER SURFACE CONTOUR BEHIND A HYDROFOIL OF MODERATE ASPECT RATIO
}

\section{by}

\section{J. Brentjes}

\begin{abstract}
Reproduction in whole or in part is permitted for any purpose of the United States Government
\end{abstract}

Hydrodynamics Laboratory

Karman Laboratory of Fluid

Mechanics and Jet Propulsion

California Institute of Technology

Pasadena, California 
An experimental program has been carried out for the measurement of the water surface contour due to a submerged hydrofoil of finite span. Because of the hydrofoil downwash, the water surface has a rather pronounced depression in the form of a long, narrow trough which extends many chords aft the hydrofoil. When the trailing vortex cores becomes sufficiently close to the water surface depression, flash ventilation of the vortices and the entire upper surface has been observed to occur abruptly.

The model used here was a hydrofoil with a NACA 16-206 section and a rectangular plan form, mounted on a NACA 16-006 strut. The hydrofoil has a chord of 3 inches and an aspect-ratio of 1.33 . It has been found that the length and depth of the surface depression, and the location of the trough bottom are well defined functions of the Froude number and of the ratio of chord-to-submergence depth. It has also been observed that the distance between the trailing vortex core and the lowest points of the depression is an important parameter in effecting the onset of ventilating flow. This investigation covers a range of flow velocity, angle of attack, depth of submergence, and the flap angle deflection. 
TABLE OF CONTENTS

Nomenclature

Introduction

1

Experimental Setup

2

Discussion of Results

4

Conclusions

6

References 
Nomenclature

$\mathrm{h}$ depth of submergence with respect to leading edge of the hydrofoil (ft.)

d' maximum surface depression with respect to undisturbed surface (ft.)

L lift force

$\ell \quad$ longitudinal or downstream distance from leading edge (ft.)

w transverse distance from hydrofoil mid-span (ft.)

c hydrofoil chord $=0.25 \mathrm{ft}$.

V water velocity (fps)

$\operatorname{Fr}=\frac{\mathrm{V}}{\sqrt{\mathrm{gC}}}$ Froude number based on chord

a angle of attack (deg)

$\mathrm{C}_{\text {L }} \quad$ lift coefficient 


\section{Introduction}

In the development of hydrofoil systems operating near the free water surface, it is important to determine the effects of the free surface on the basic characteristics of hydrofoil performance. Other than its effects on the lift, wave drag, moment of force of a hydrofoil, the free surface has an additional important effect on the change of the basic flow configuration by the inception of cavitation and ventilation about the hydrofoil. The formation of an air bubble by ventilation at the tips and upper surface of a submerged flat plate has been shown and discussed by Wadlin, Ramsen and Vaughan (1)*. It was reported that when the flow velocity past a hydrofoil, held at high angles of attack and submerged at shallow depths, is sufficiently large, air was observed to enter the trailing vortices from downstream. As the speed was increased the entrained air proceeded forward along a helical path inside the vortices until it reached the model, causing the entire upper side to be ventilated.

Similar observations have been made at this Hydrodynamics Laboratory using a hydrofoil with a NACA 16-206 section and a rectangular plan form. A $16 \mathrm{~mm}$ motion picture (Ref. 2) presents some typical observations and experimental results, showing the effect of speed, angle of attack, operating depth and flap angles on the ventilation characteristics.

These experimental observations showed that due to the hydrofoil downwash, the water surface had a rather pronounced depression in the form of a long, narrow trough which extended many chords aft the hydrofoil, but before the well known wave pattern would be established further downstream. The results gave evidences that this water surface depression was very important to the initiation of ventilation. Apparently, this surface depression brings the free surface closer to the trailing vortices which represent a low pressure region (compared with

Number in parenthesis indicate the references at the end of text. 
the ambient) in the flow; hence air bubbles tend to migrate from the surface to the low pressure field of the tip vortices. When the depth of submergence was sufficiently small, and these vortex cores sufficiently close to the surface depression, flash ventilation of the vortices and the entire upper surface was observed to occur abruptly.

As was pointed out in Ref. (1) and later in (3), when the upper surface becomes ventilated, the lift of the hydrofoil suddenly drops by as much as 45 percent. This loss in lift and the large downstream dis turbances produced by the trailing cavities are the important reasons for studying this phenomena from the standpoint of engineering application. The problem is also of interest in view of the determination of the critical conditions for ventilation inception and its bearing on related free-boundary flows. Consequently, it was decided to explore in a systematic manner the mechanism and conditions under which this type of ventilation takes place.

The first part of these studies involved the determination of the water surface contour behind a hydrofoil. Three important parameters --depth of submergence, velocity, angle of attack--were considered in this experimental program. Aspect ratio, though it can be important, was kept fixed in this study. Measurements were made of the surface contour, and in particular, the magnitude and location of the maximum surface depression were recorded for several velocities, angles of attack and foil depths.

\section{Experimental Setup}

The hydrofoil used in this experimental program was the NACA 16-206 section without flap. The chord of the hydrofoil was three inches and the span four inches; hence the aspect ratio was 4/3. There was no taper and the tips were square and parallel to each other. The foil was mounted at mid-span on a ten inch long strut which had a NACA 16-006 section profile and a chord of 2.25 inches. Table I shows the coordinates of the strut and foil.

The model was tested in the Free-Surface Water Tunnel which 
has a test section 20 inches wide and eight feet long. The water depth under normal operating conditions is about 20 inches. Although it was recognized that the water surface contour could be a sensitive function of channel depth, width, and velocity, the effect of changes in channel geometry were not explored in these preliminary experiments. Figure 1 shows the apparatus used in this program. The model was supported from an elevating mechanism which permits the model to be positioned vertically with a repeatability of 0.001 feet. The water surface contour was determined with a depth gage which could be positioned at various distances behind and to the side of the model. The longitudinal distance, $\ell$, was measured from the leading edge of the hydrofoil and the transverse distance, w, was measured from the centerline of the model. The reference level of the surface was taken to be the water surface in the absence of the model. This reference surface was determined with the depth gage for each run with a different velocity, since the water surface level is affected slightly by the tunnel speed. The reference depth of the foil was determined during each run by lowering the model to the water surface until the trailing edge just touched the water surface. A correction of $\Delta \mathrm{h}=\mathrm{csina}$, where $\mathrm{c}$ denotes the chord and a the angle of attack, was applied to account for the vertical distance between the leading and trailing edges of the hydrofoil. Thus the reference position of the hydrofoil depth is taken to be the distance from the leading edge to the undisturbed water surface at all times.

The water surface contour was measured for the velocity $V$ equal to $10,15,20$, and 24.5 feet per second, with angle of attack a held at 2, 4, and 8 degrees, and depth-to-chord ratio set at 1.0, 0.5, and 0.25 . Figures 4 through 8 show the resulting contours to scale. The maximum water surface depression $d^{\prime}$, was investigated further for a large number of foil depths and also for -4 degrees angle of attack. These results are shown in Figs. 9 and 10. Figure 11 shows the relationship between water depth and Froude number and also the lift coefficient. This lift coefficient data was obtained from Ref. (3), which presents the results of a test program conducted with the present hydro- 
foil in the Free-Surface Water Tunnel.

\section{Discussion of Results}

The effect of foil submergence on the extent of the water surface displacement is most significant. This effect is seen in the photographs of Fig. 3 and in the measured surface profiles of Fig. 4. This latter figure is drawn to scale for a velocity of $15 \mathrm{fps}$ and $8^{\circ}$ angle of attack. It shows how the water surface at the centerline gradually slopes downward to a point which is about eight chords aft the leading edge of the hydrofoil. At $15 \mathrm{fps}$, this is the observed position of the maximum surface depression for all depths of submergence tested with this hydrofoil model. Downstream of this location the surface rises up again and begins to form a "rooster tail" at the centerline. The graphs of Figs. 5 and 6 give further information on the effect of angle of attack and the Froude number on the surface contour. The transverse profiles in Fig. 7 show how the rooster tail downstream of the hydrofoil develops. The growth of the rooster tail along the centerline is particularly noticeable at a velocity of $10 \mathrm{fps}$ and, as can be seen, it rises above the undisturbed water level. This same phenomenon also occurred at higher velocities, but it took place further downstream (at the entrance of the tunnel diffuser) where it could not be measured.

The effect of angle of attack on the water surface profile is illustrated in Fig. 5. Again the maximum depth of the surface depression occurred eight chord lengths aft of the leading edge. Thus it seems that the longitudinal location of the maximum surface depression depends only on the velocity or, rather, on the Froude number based on chord. It is interesting to note also that the rooster tail formed only at moderate and high angles of attack; for the angle of attack about 2 and 4 degrees, the water surface tended to smooth out very gradually far downstream.

Figure 6 shows the effect of velocity on the longitudinal surface depression for an angle of attack of $8^{\circ}$. At 24.5 feet per second the depth of the water trough became tremendous and extended very 
far downstream. For these same conditions the transverse profiles are presented in Fig. 7. Note that the cross sections were taken at regular intervals from the foil leading edge. The star indicates the approximate location of maximum water depth, d'. Although the length and depth of the surface depression increased with velocity, the width of the trough at the surface as well as at its deepest point was smaller for the high velocities. This is an important result from the standpoint of incipient tip ventilation. As was discussed before, the ventilation was always triggered from this trough, and proceeded forward to the foil tips. When the low local pressure field in the tip vortices becomes so close to the water surface, a passage is formed for the air to enter the vortex. Hence if the distance from these tip vortices to the surface is sufficiently large, ventilation will not occur at all.

In order to determine the effect of model depth, and of angle of attack on the surface depression depth $d^{\prime}$ in greater detail, a large number of readings of $d^{\prime}$ were taken at small intervals of foil depth. The effect of the Froude number is shown in Fig. 9. The most interesting result here is that the surface depression did not occur when hydrofoil was right at the water surface, but rather when it was somewhat below the surface. In fact, with an increase in the Froude number, the submergence required for maximum surface depression increased also. It should be noted here that the reason for negative surface depression is the fact that the foil depth was measured with respect to the foil leading edge. Hence for the negative values of $\mathrm{h} / \mathrm{c}$ the hydrofoil was planing. The dashed line in this Fig. 9 marks the points at which the tip vortices began to ventilate. When the hydrofoil was raised from a deep submergence toward the free surface, the ventilated tip vortices formed at these points. The ventilation of the entire upper surface occurred after the maximum value of $d^{\prime}$ had been reached. This state of ventilation will be called superventilation. The hydrofoil depth at which this superventilation was initiated varied from test to test somewhat and the individual points are, therefore, not marked. There was a considerable hysteresis effect on tip ventilation and superventilation. When the hydro- 
foil was lowered below the point of incipient ventilation, after having established ventilation, the cavity would remain for many seconds until all the air had finally entrained and disappeared downstream. In the case of the ventilated tip vortices, the cavity would disappear downstream only when about 1.5 to 2 chords depth was reached. A more detailed study of these effects will be made in the future. Figure 10 illustrates the effect of angle of attack on the maximum depth of the surface depression. It can be seen that the foil depth at which the maximum value of $d^{\prime}$ was measured did not change appreciably with positive angles of attack. In the case of $a=-4^{\circ}$ the water surface was actually deflected upward. At values of $\mathrm{h} / \mathrm{c}$ about 0.1 the lower surface of the hydrofoil became ventilated and a relatively thin sheet of water was scooped up by the upper surface. The large negative value of d'/c at small foil submergences represents this sheet of water.

The dependence of the maximum surface depth for various submergence ratios is shown as a funtion of lift coefficient in Fig. 11 and the Froude number in Fig. 12. It is of interest to note from Fig. 12 that the depth-chord ratio is nearly linearly proportional to the Froude number. A theoretical analysis of this depression has been carried out by D. K. Ai and T. Y. Wu, the numerical results of this work will be presented in a future report. It is hoped that this work will explain the salient features of these graphs.

4. Conclusions

From this preliminary experimental study of the water surface contour behind a submerged hydrofoil, the following general conclusions can be made:

1) The surface depression is greatest along the centerline at a distance downstream which is directly related to the Froude number.

2) The maximum depression of the water surface is nearly linearly dependent on lift coefficient and Froude number. 
3) The maximum depth increases rapidly with a decrease in foil submergence and attains a maximum value between depth-chord ratio of 0.1 and 0.4 , depending on the Froude number.

As the hydrofoil approaches the water surface ventilated tip vortices first appear, followed by superventilation when the foil is at 0.1 to 0.2 chords depth. These air entrainment problems will be studied in more detail in the future. It would be of particular interest to determine the conditions for ventilation of the initial vortex and subsequent superventilation, and the conditions under which the ventilated cavity will disappear again. 
R E F ER ENCES

1. Wadlin, K. L., Ramsen, J. A., Vaughan, V. L., Jr. : "The Hydrodynamic Characteristics of Modified Rectangular Flat Plates Having Aspect Ratios of 1.00, 0.25, and 0.125 and Operating Near a Free Water Surface", NACA Report 1246, 1955.

2. Brentjes, J. : "Ventilation Characteristics of a Parabolic and NACA 16-206 Hydrofoil", 16 mm Sound Motion Picture No. 62, Contract Nonr-220(43), Hydrodynamics Laboratory, California Institute of Technology, 1962.

3. Brentjes, J. : "Experimental Force Investigation of a NACA 16-206 Hydrofoil in the California Institute of Technology Free Surface Water Tunnel", Boeing Document D2-11597, Boeing Company, Seattle, Washington, July, 1961. 
TABLE I

HYDROFOIL AND STRUT COORDINATES

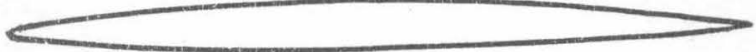

NACA 16-206

NACA $16-006$

\begin{tabular}{|c|c|c|c|c|c|}
\hline \multicolumn{4}{|c|}{ NACA $16-206$} & \multicolumn{2}{|c|}{ NACA $16-006$} \\
\hline \multicolumn{4}{|c|}{ HY DROFOIL } & \multicolumn{2}{|c|}{ STRUT } \\
\hline $\mathrm{x}_{\mathrm{u}}$ & $\mathrm{Y}_{\mathrm{u}}$ & $\mathrm{x}_{\ell}$ & $\mathrm{Y}_{\ell}$ & $\mathrm{X}$ & $\mathrm{Y}_{\mathrm{u}}, \mathrm{Y}_{\boldsymbol{\ell}}$ \\
\hline $\begin{array}{l}0 . \\
0.0362 \\
0.0734 \\
0.1482 \\
0.2232 \\
0.2920 \\
0.4483 \\
0.5984 \\
0.8989 \\
1.1994 \\
1.5000 \\
1.8006 \\
2.1010 \\
2.4014 \\
2.7013 \\
2.8510 \\
3.000\end{array}$ & $\begin{array}{l}0 . \\
0.0225 \\
0.0326 \\
0.0467 \\
0.0582 \\
0.0674 \\
0.0822 \\
0.0938 \\
0.1104 \\
0.1199 \\
0.1231 \\
0.1196 \\
0.1082 \\
0.0868 \\
0.0532 \\
0.0307 \\
0 .\end{array}$ & $\begin{array}{l}0 . \\
0.0383 \\
0.0766 \\
0.1518 \\
0.2268 \\
0.3018 \\
0.4517 \\
0.6016 \\
0.9011 \\
1.2006 \\
1.5000 \\
1.7994 \\
2.0990 \\
2.3986 \\
2.6587 \\
2.8499 \\
3.0000\end{array}$ & $\begin{array}{l}0 . \\
0.01611 \\
0.0215 \\
0.0286 \\
0.0327 \\
0.0363 \\
0.0418 \\
0.0461 \\
0.0521 \\
0.0557 \\
0.0569 \\
0.0554 \\
0.0499 \\
0.0391 \\
0.0222 \\
0.0117 \\
0 .\end{array}$ & $\begin{array}{l}0 . \\
0.0281 \\
0.0563 \\
0.1125 \\
0.1683 \\
0.2250 \\
0.3375 \\
0.4500 \\
0.6750 \\
0.5000 \\
1.1250 \\
1.3500 \\
1.5750 \\
1.8000 \\
2.0250 \\
2.1375 \\
2.2500\end{array}$ & $\begin{array}{l}0 . \\
0.0145 \\
0.0203 \\
0.0282 \\
0.0341 \\
0.0389 \\
0.0465 \\
0.0535 \\
0.0610 \\
0.0659 \\
0.0675 \\
0.0656 \\
0.0593 \\
0.0472 \\
0.0283 \\
0.0159 \\
0.0014\end{array}$ \\
\hline \multicolumn{4}{|c|}{$\begin{array}{l}\text { L. E. RADIUS }=0.00176 " \\
\text { SLOPE OF RADIUS THROUGH L. E. }=.0824\end{array}$} & \multicolumn{2}{|c|}{ L. E. RADIUS $=.00396$} \\
\hline
\end{tabular}




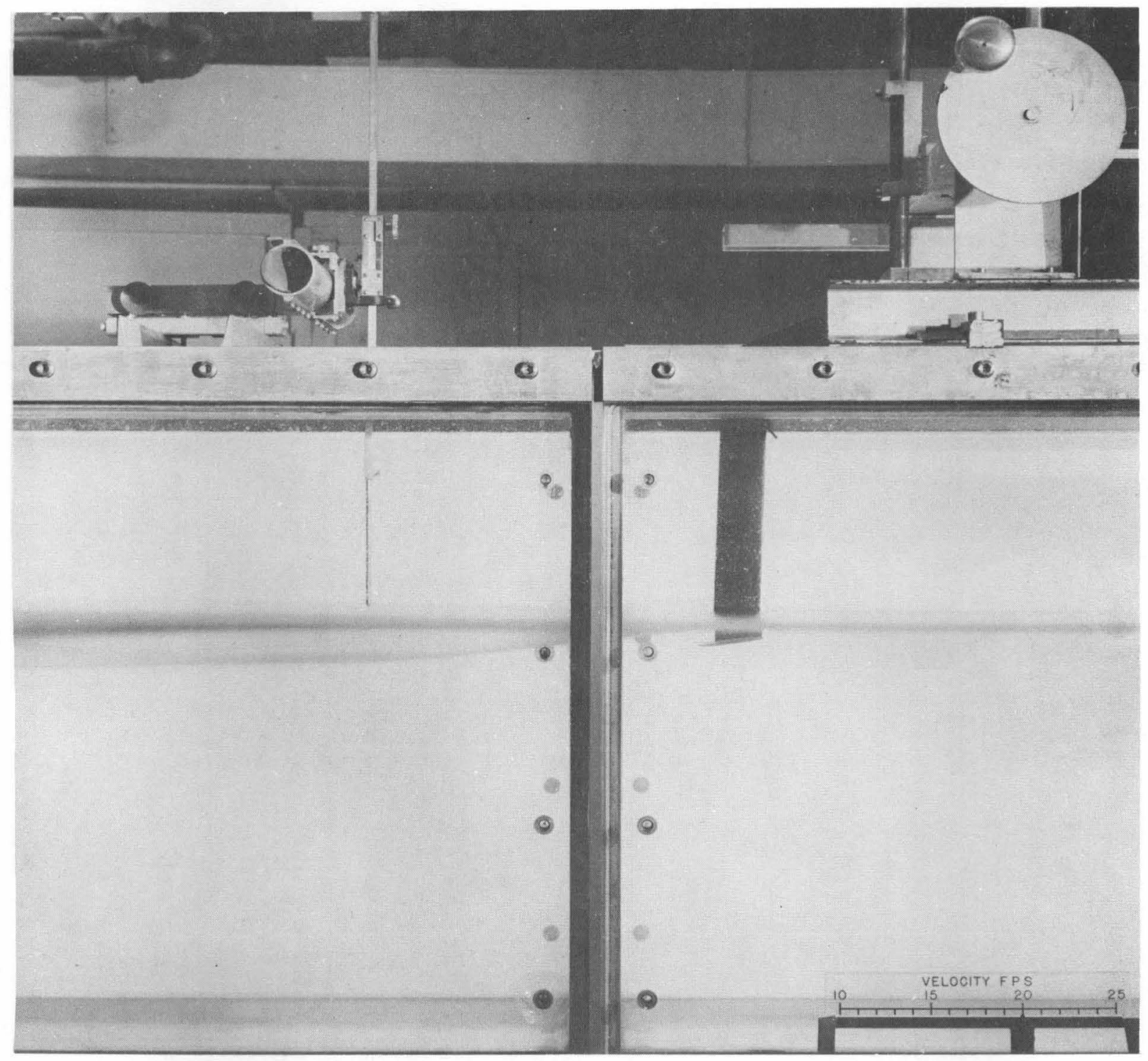

Figure 1. Photograph showing strut-mounted hydrofoil in test section of Free-Surface Water Tunnel. The tunnel velocity is $20 \mathrm{ft}$. per sec. at an angle of attack of $8^{\circ}$ and the submergence ratio $(\mathrm{h} / \mathrm{c})$ is 0.25 . The following legend identifies the objects in the photograph:

(1) Hydrofoil and strut system, (2) Strut support, (3) Depth gage and traversing mechanism, (4) Velocity indicator. 


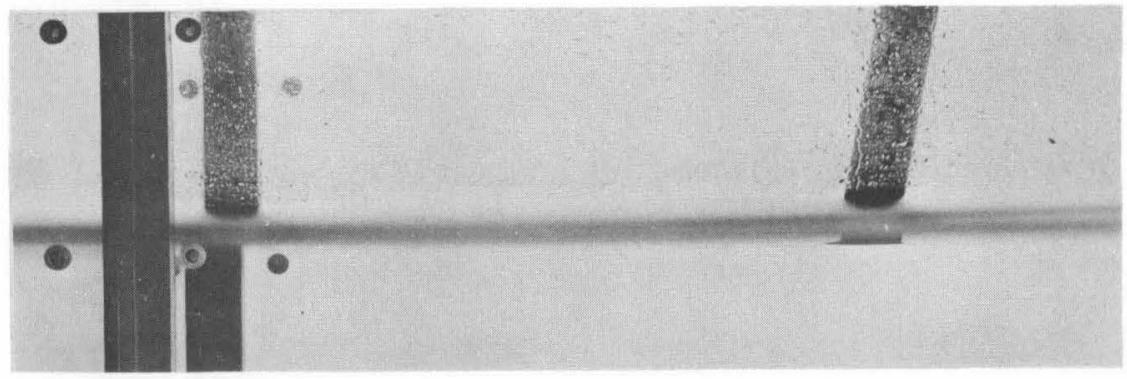

Angle of Attack $=0^{\circ}, \quad \mathrm{C}_{\mathrm{L}}=0.015$

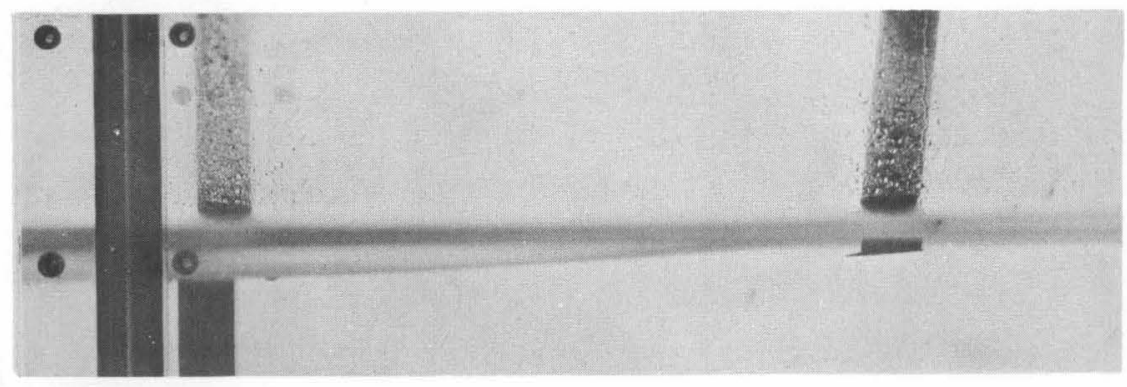

Angle of Attack $=4^{\circ}, \quad C_{L}=0.120$

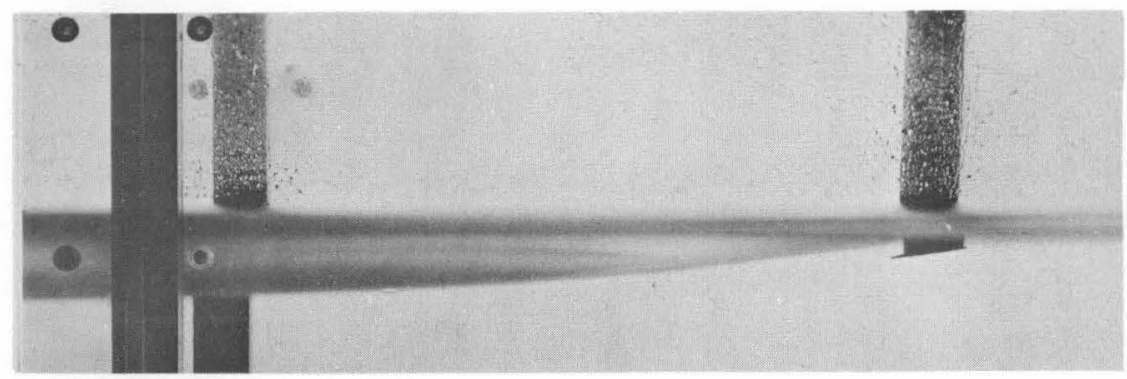

Angle of Attack $=8^{\circ}, \mathrm{C}_{\mathrm{L}}=0.232$

Figure 2. Photographs of water surface depression behind hydrofoil at various angles of attack. The ratio of the submergence to the chord is 0.24 and the velocity is $24 \mathrm{ft}$. per sec. 


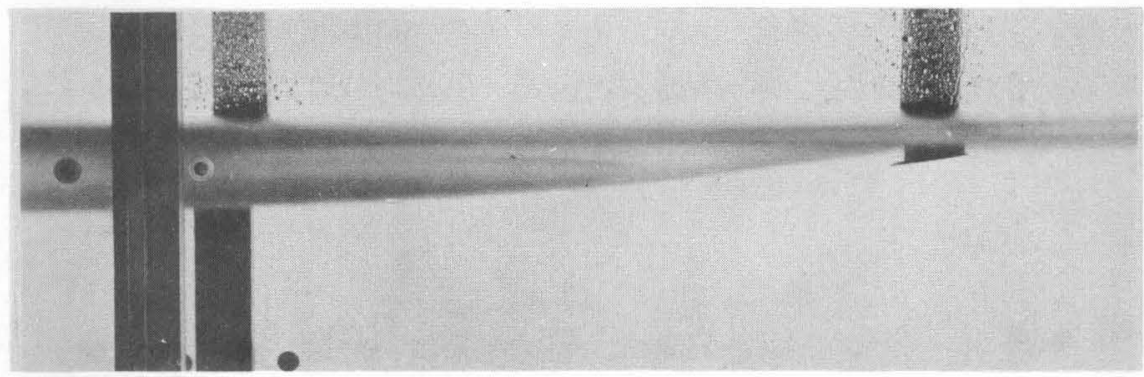

$$
\mathrm{h} / \mathrm{c}=.236, \mathrm{C}_{\mathrm{L}}=0.230
$$

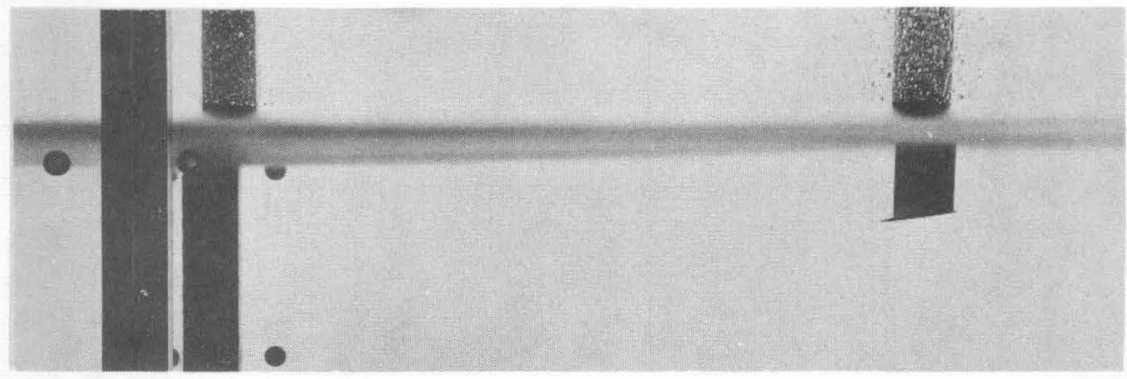

$$
\mathrm{h} / \mathrm{c}=.98, \quad \mathrm{C}_{\mathrm{L}}=0.323
$$

Figure 3. Effect of submergence on the depression of the water surface. In each case the water velocity is $24.5 \mathrm{ft}$. per sec. and the angle of attack is $8^{\circ}$. 

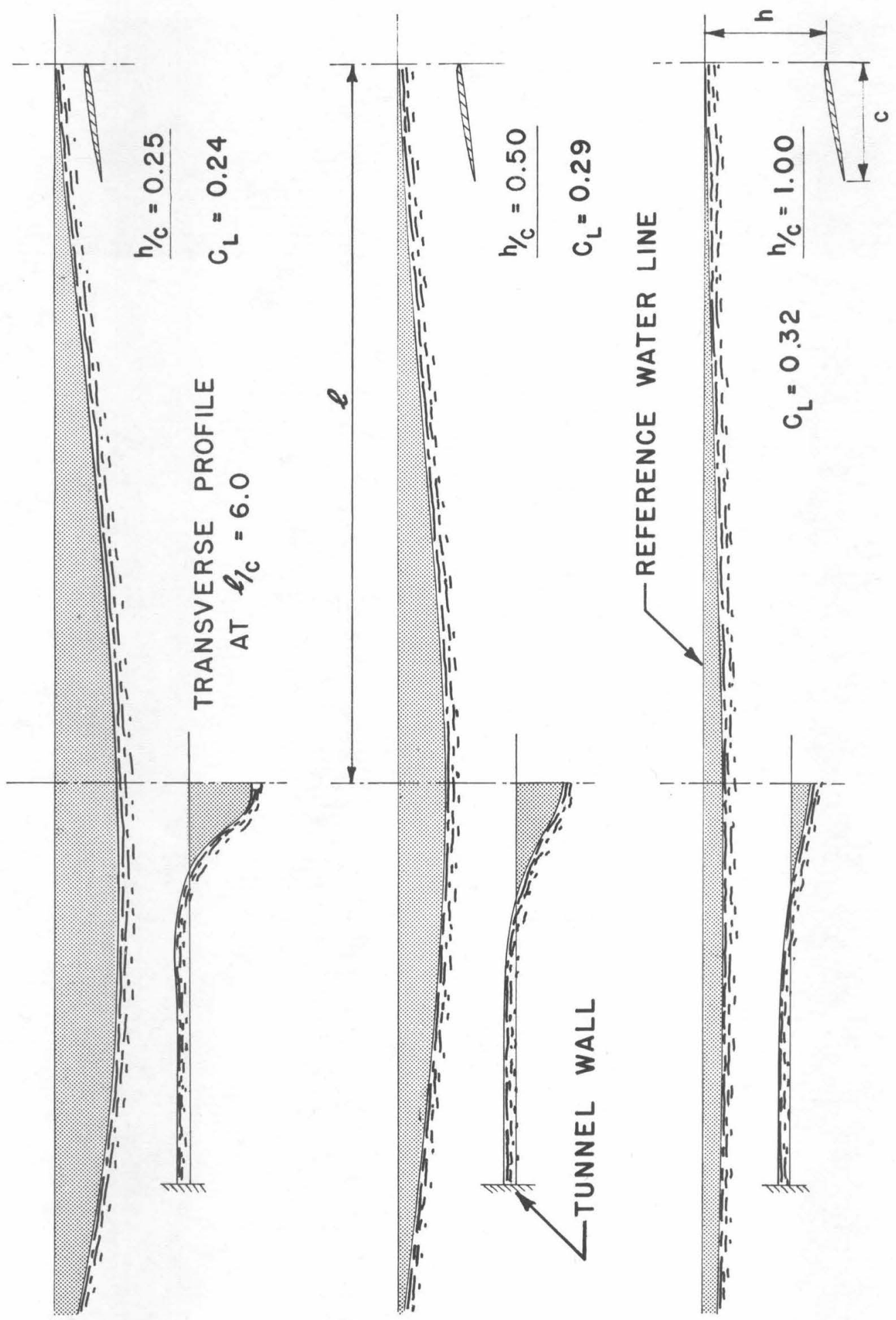

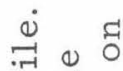

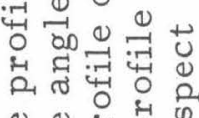
0)

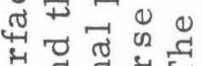
गี

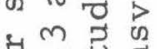
แै.

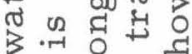

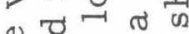

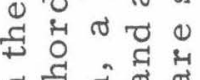
दोधी की त द्व क्ष द्व द्व

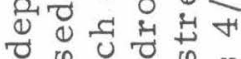

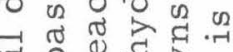
न-1

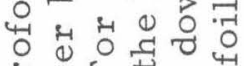
岑兘红 थ

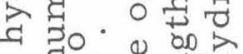
फ $\infty$ द द्व

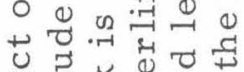
U

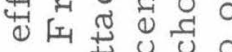

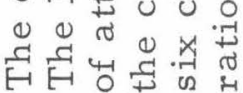

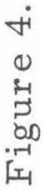




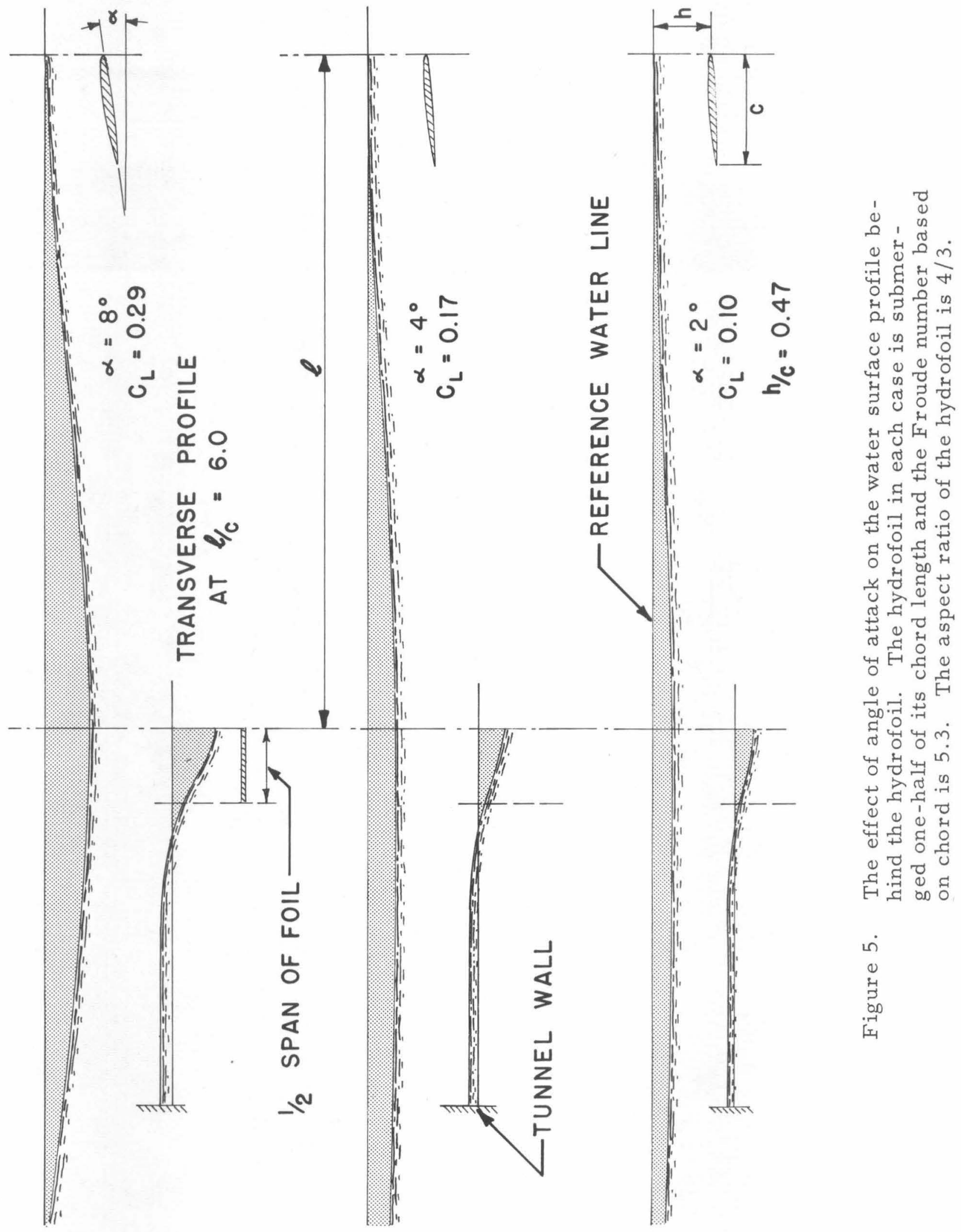



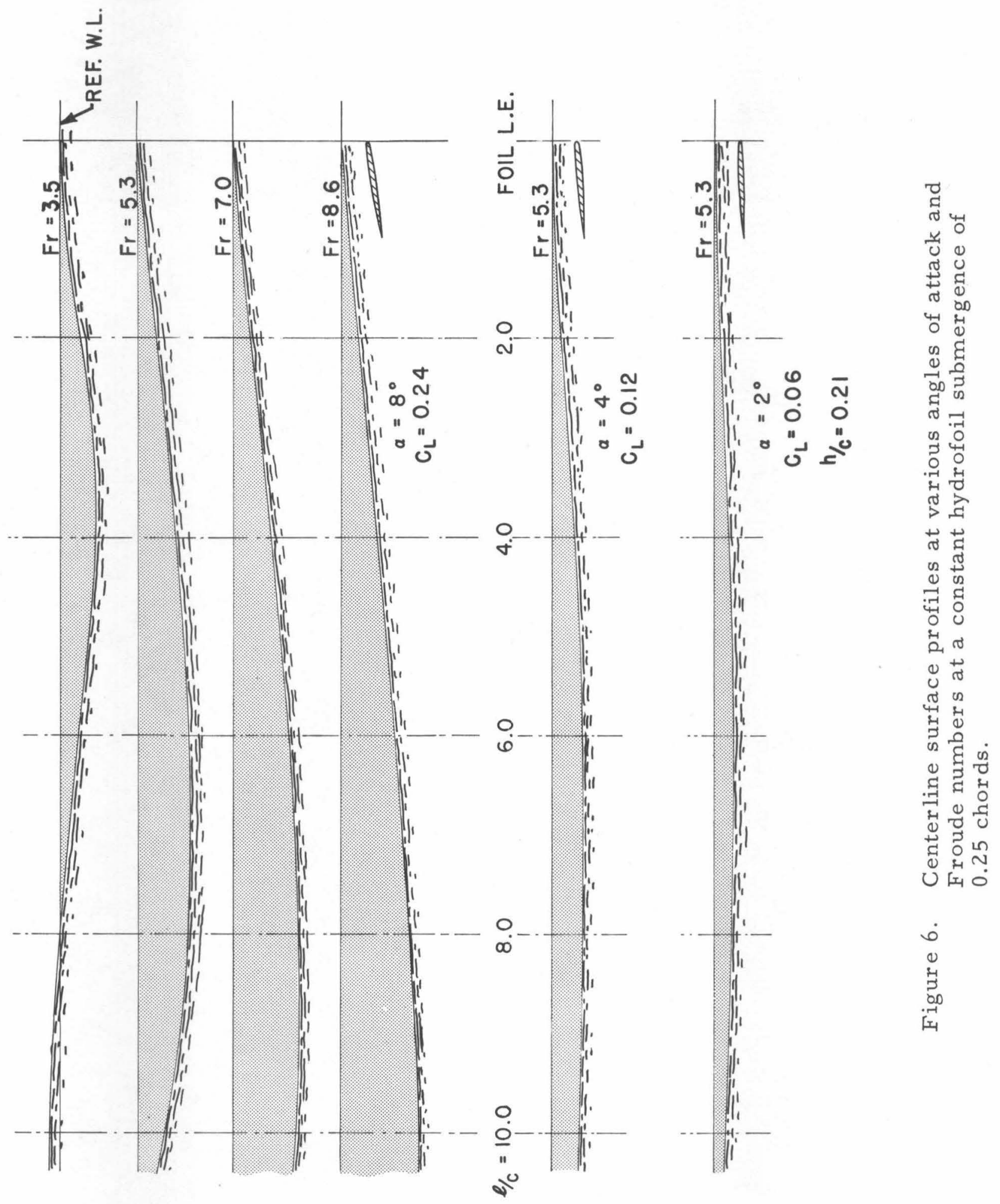


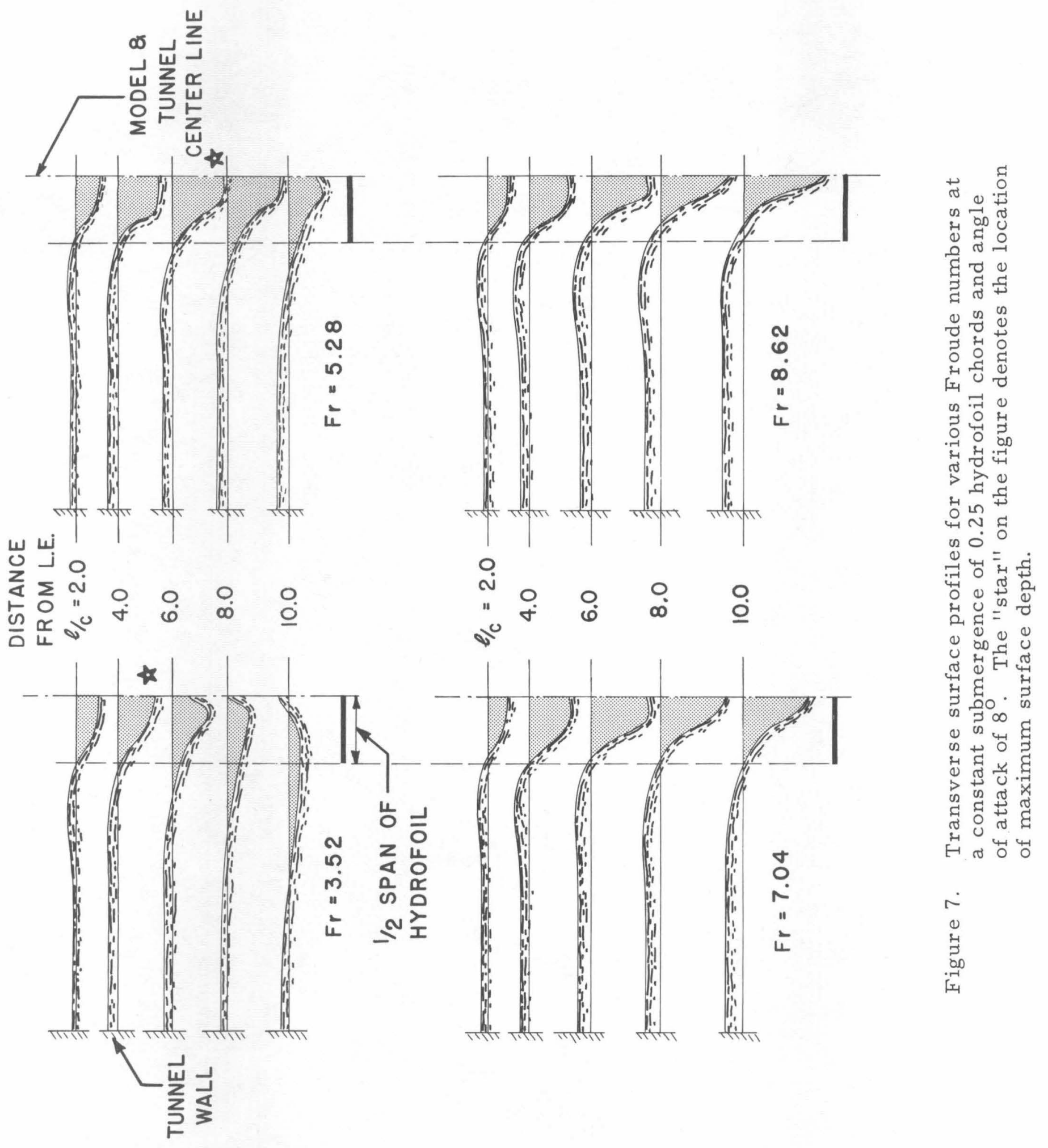




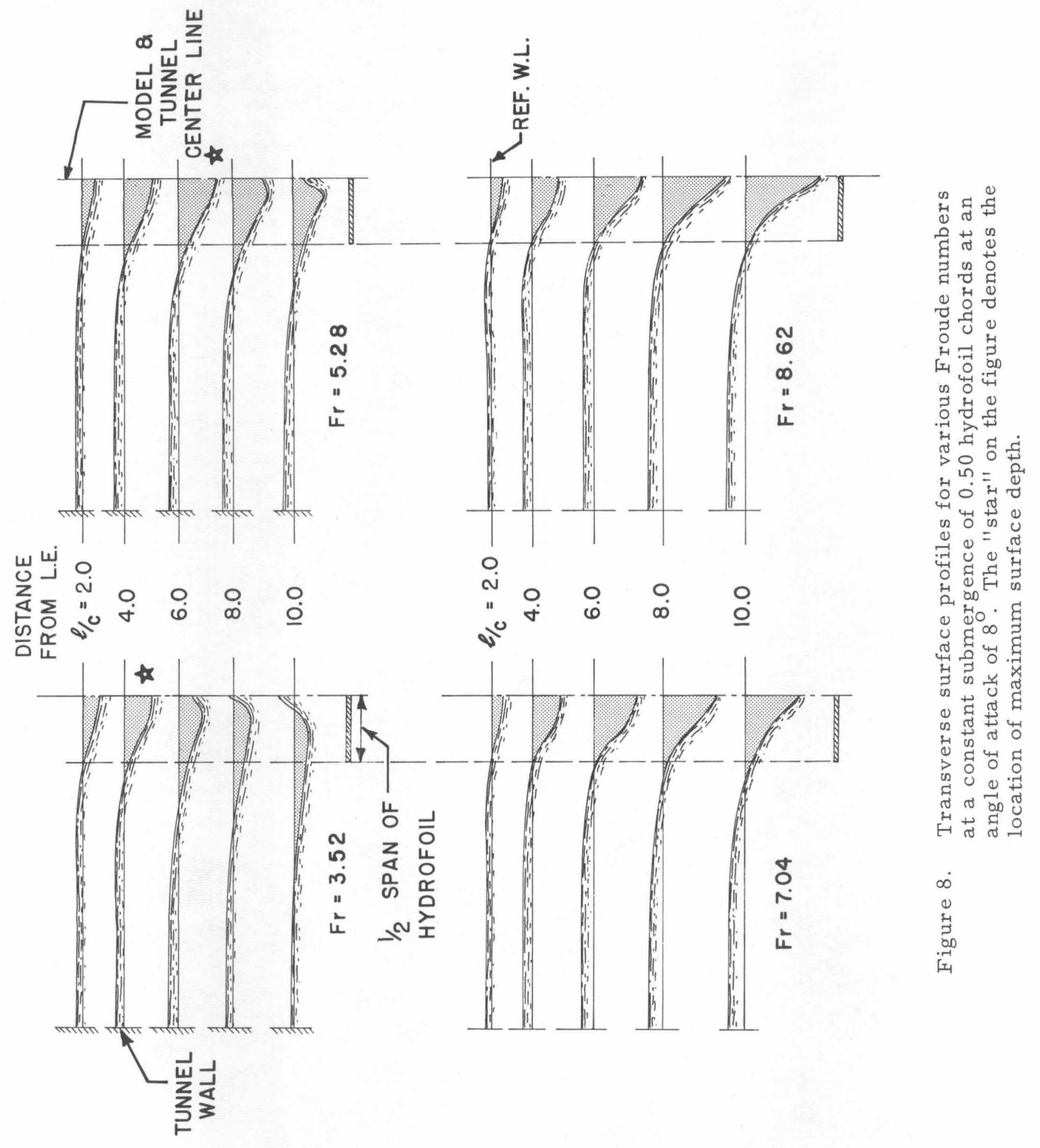




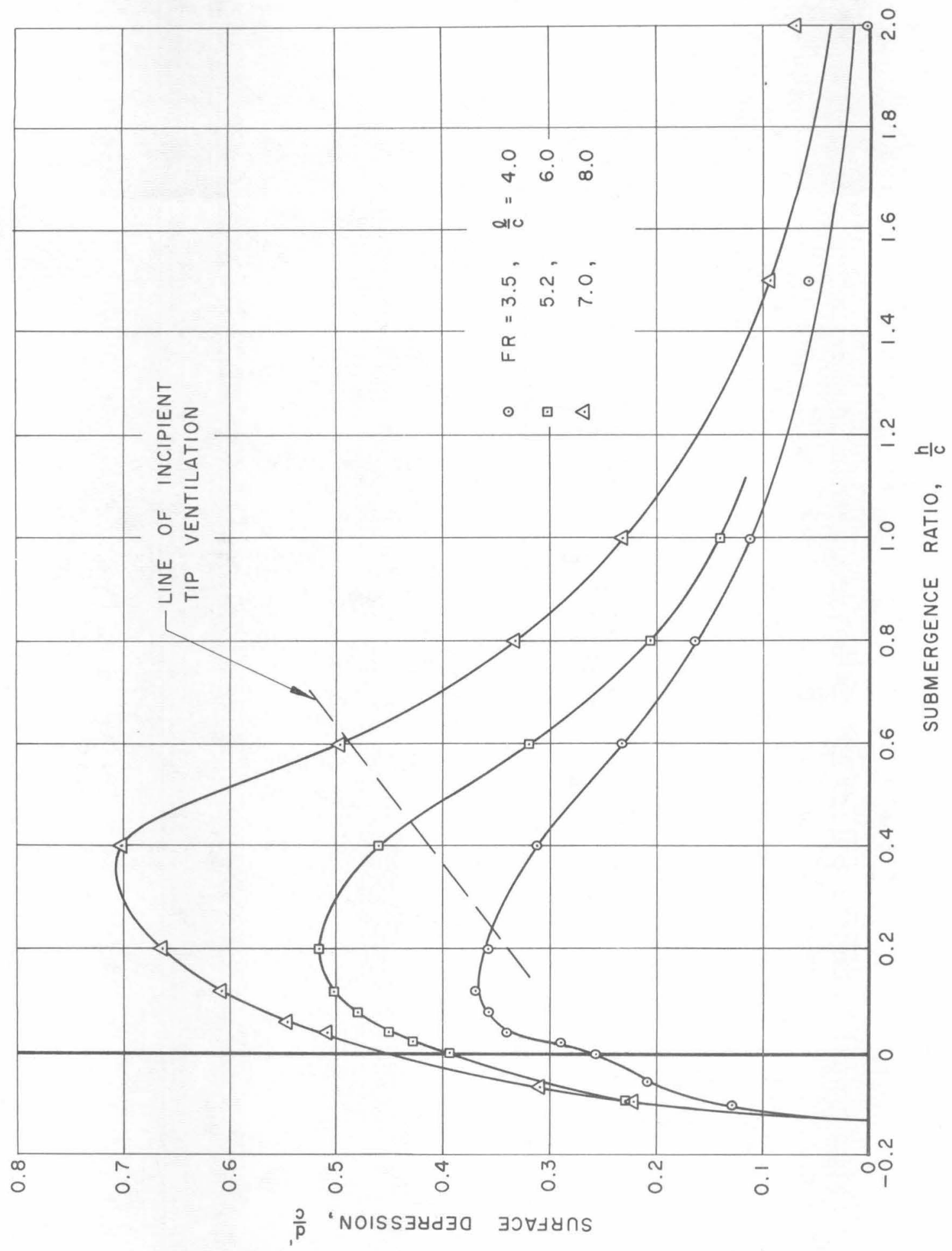

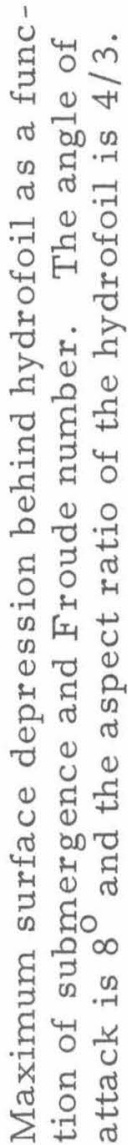

o

10 


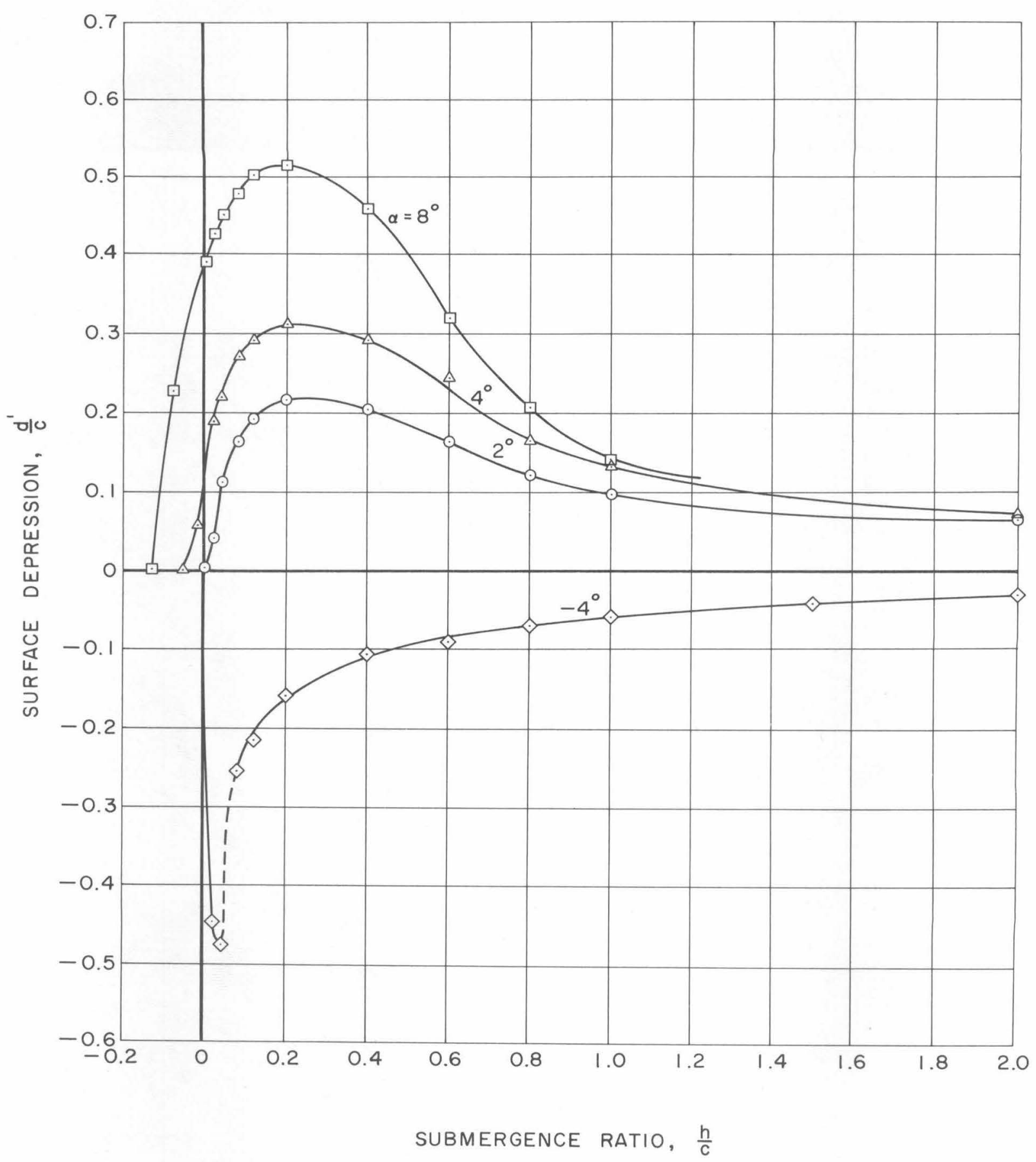

Figure 10. Maximum surface depression behind hydrofoil as a function of submergence ratio and angle of attack. The Froude number is 5.28 (based on chord) for all angles. The as pect ratio of the hydrofoil is $4 / 3$. 


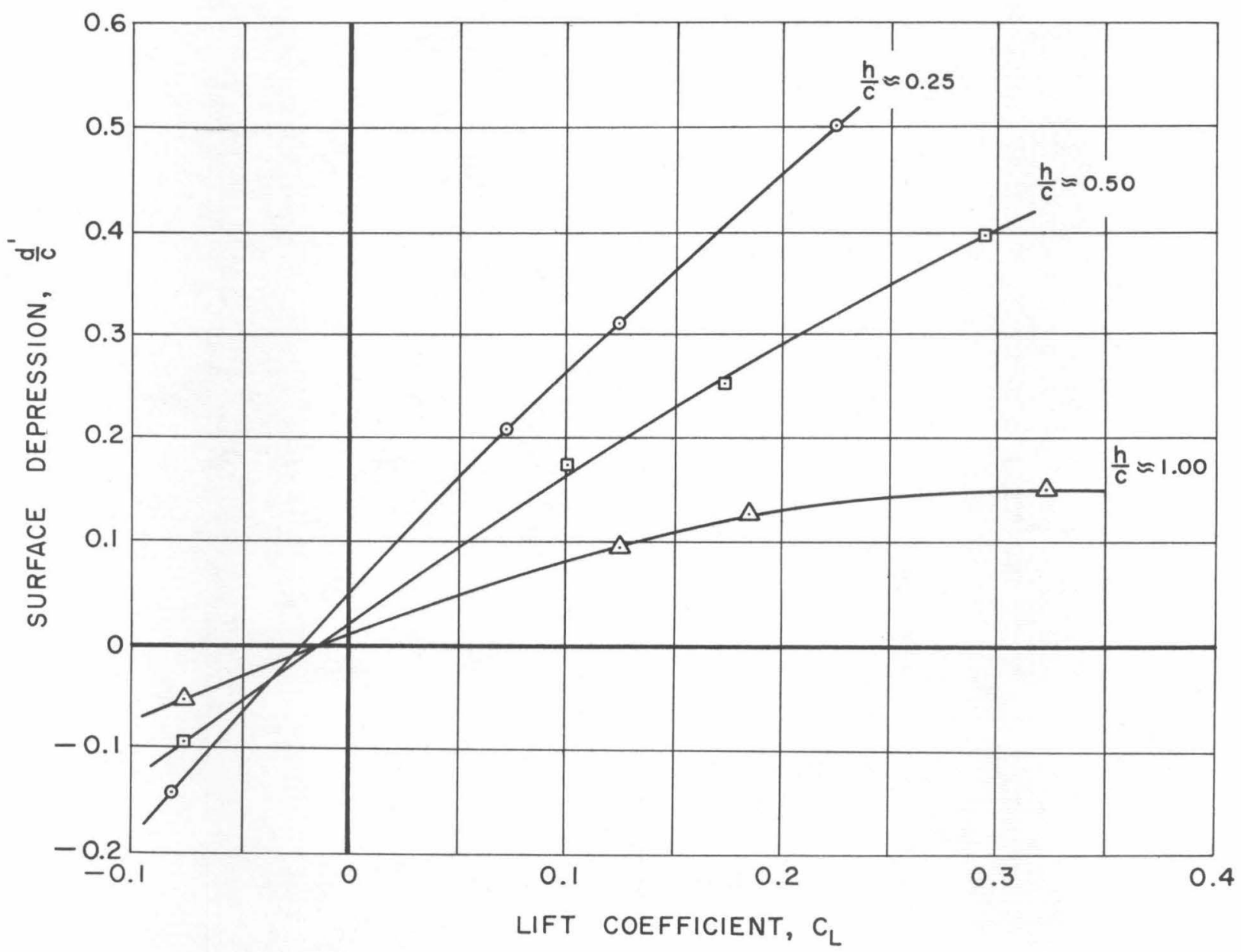

Figure 11. Maximum surface depression as a function of depth and lift coefficient for a Froude number of 5.3 (based on chord). The aspect ratio is $4 / 3$. 


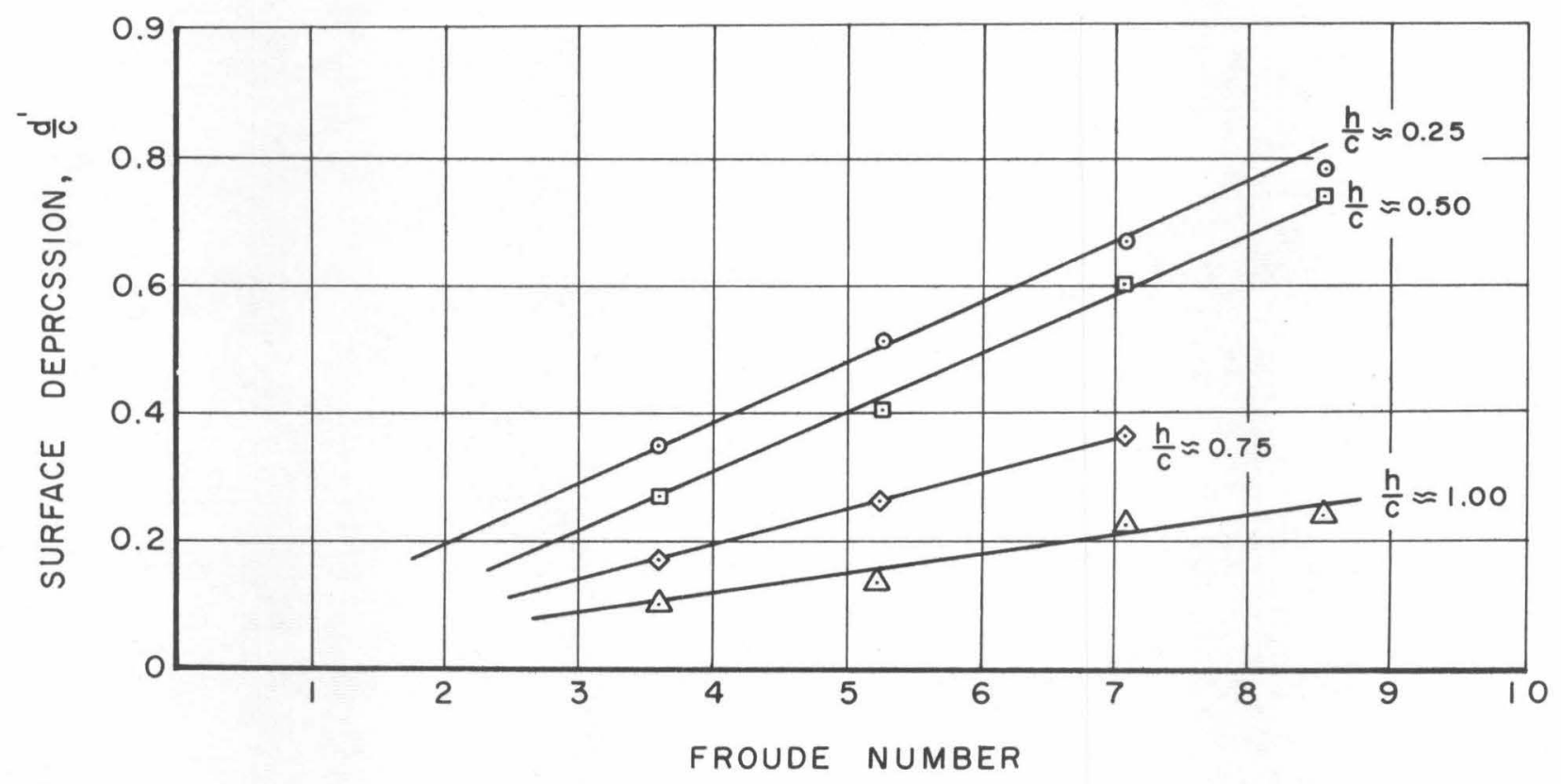

Figure 12. Maximum surface depression as a function of Froude number and submergence ratio. 


\section{DISTRIBUTION LIST FOR UNCLASSIFIED TECHNICAL REPORTS \\ ISSUED UNDER CONTRACT Nonr-220(43) \\ (Single copies unless otherwise specified)}

Chief of Naval Research Department of the Navy Washington 25, D.C. Attn: Codes 438 (3) 461 463 466

Commanding Officer Office of Naval Research Branch Office 495 Summer Street

Boston 10, Massachusetts

Commanding Office $r$ Office of Naval Research Branch Office 207 West 24th Street New York 11, New York

Commanding Officer Office of Naval Research

Branch Office 1030 East Green Street

Pasadena, California

Commanding Officer Office of Naval Research

Branch Office

1000 Geary Street

San Francisco 9, California

Commanding Officer

Office of Naval Research

Branch Office

Box 39, Navy No. 100

Fleet Post Office

New York, New York (25)

Director

Naval Research Laboratory

Washington 25, D. C.

Attn: Code 2027 (6)

Chief, Bureau of Naval Weapons

Department of the Navy

Washington 25, D. C.

Attn: Codes RUAW -r

RRRE

RAAD

RAAD- 222

DIS -42

Commander

U. S. Naval Ordnance Test Station

China Lake, California

At.tn: Code 753
Chief, Bureau of Ships

Department of the Navy

Washington 25, D. C.

Attn: Codes 310

312

335

420

421

440

442

449

Chief, Bureau of Yards and Docks Department of the Navy

Washington 25, D. C.

Attn: Code D-400

Commanding Officer and Director David Taylor Model Basin

Washington 7, D. C.

Attn: Codes 108

142

500

513

520

525

526

$526 \mathrm{~A}$

530

533

580

585

589

591

$591 \mathrm{~A}$

700

Commander

U.S. Naval Ordnance Test Station

Pasadena Annex

3202 E. Foothill Blvd.

Pasadena 8, California

Attn: Code P-508

Commander

Planning Department

Portsmouth Naval Shipyard

Portsmouth, New Hampshire

Commander

Planning Department

Boston Naval Shipyard

Boston 29, Massachusetts 
Commander

Planning Department

Pearl Harbor Naval Shipyard

Navy No, 128 , Fleet Post Office

San Francisco, California

Commander

Planning Department

San Francisco Naval Shipyard

San Francisco 24, California

Commander

Planning Department

Mare Island Naval Shipyard

Vallejo, California

Commander

Planning Department

New York Naval Shipyard

Brooklyn 1, New York

Commander

Planning Department

Puget Sound Naval Shipyard

Bremerton, Washington

Commander

Planning Department

Philadelphia Naval Shipyard

U. S. Naval Base

Philadelphia 12, Pennsylvania

Commander

Planning Department

Norfolk Naval Shipyard

Portsmouth, Virginia

Commander

Planning Department

Charleston Naval Shipyard

U. S. Naval Base

Charleston, South Carolina

Commander

Planning Department

Long Beach Naval Shipyard

Long Beach 2, California

Commande $\mathrm{r}$

Planning Department

U. S. Naval Weapons Laboratory

Dahlgren, Virginia

Commander

U. S. Naval Ordnance Laboratory

White Oak, Maryland

Dr. A. V. Hershey

Computation and Exterior

Ballistics Laboratory

U. S. Naval Weapons Laboratory

Dahlgren, Virginia
Superintendent

U. S. Naval Academy

Annapolis, Maryland

Attn: Library

Superintendent

U. S. Naval Postgraduate School

Monterey, California

Commandant

U. S. Coast Guard

1300 E. Street, N. W.

Washington, D. C.

Secretary Ship Structure Committee

U. S. Coast Guard Headquarters

1300 E Street, N. W.

Washington, D. C.

Commander

Military Sea Transportation Service

Department of the Navy

Washington 25, D. C.

U. S. Maritime Administration

GAO Building

441 G Street, N. W .

Washington, D. C.

Attn: Division of Ship Design

Division of Research

Supe rintendent

U. S. Merchant Marine Academy

Kings Point, Long Island, New York

Attn: Capt. L. S. McCready

(Dept. of Engineering)

Commanding Officer and Director

U. S. Navy Mine Defense Laboratory

Panama City, Florida

Commanding Officer

NROTC and Naval Administrative

Massachusetts Institute of Technology

Cambridge 39, Massachusetts

U. S. Army Transportation Research and

Development Command

Fort Eustis, Virginia

Attn: Marine Transport Division

Mr. J. B. Parkinson

National Aeronautics and Space

Administration

1512 H Street, N. W.

Washington 25, D. C.

Director

Langley Research Center

Langley Station

Hampton, Virginia

Attn: Mr. I. E. Garrick

Mr. D. J. Marten 
Director Engineering Sciences Division National Science Foundation 1951 Constitution Avenue, N. W. Washington 25, D. C.

Director

National Bureau of Standards Washington 25, D. C.

Attn: Fluid Mechanics Division (Dr. G. B. Schubauer) Dr. G. H. Keulegan Dr. J. M. Franklin

Defense Documentation Center

Cameron Station

Alexandria, Virginia

Office of Technical Services

Department of Commerce

Washington 25, D. C.

California Institute of Technology

Pasadena 4, California

Attn: Professor M. S. Plesset

Professor T. Y. Wu

Professor A. J. Acosta

University of California

Department of Engineering

Los Angeles 24, California

Attn: Dr. A. Powell

Director

Scripps Institute of Oceanography

University of California

La Jolla, California

Professor M. L. Albertson

Department of Civil Engineering

Colorado $\mathrm{A}$ and $\mathrm{M}$ College

Fort Collins, Colorado

Professor J. E. Cermak

Department of Civil Engineering

Colorado State University

Fort Collins, Colorado

Professor W. R. Sears

Graduate School of Aeronautical Engineering Ordnance Research Laboratory

Cornell University

Ithaca, New York

State University of Iowa

Iowa Institute of Hydraulic Research

Iowa City, Iowa

Attn: Dr. H. Rouse

Dr. L. Landweber

Massachusetts Institute of Technology

Cambridge 39, Massachusetts

Attn: Department of Naval Architecture Woods Hole, Massachusetts

and Marine Engineering

Professor A. T. Ippen
Harvard University

Cambridge 38, Massachusetts

Attn: Professor G. Birkhoff

(Dept. of Mathematics)

Professor G. F. Carrier

(Dept. of Mathematics)

University of Michigan

Ann Arbor, Michigan

Attn: Professor R. B. Couch

(Dept. of Naval Architecture)

Professor W. W. Willmarth

(Aero. Engineering Department)

Dr. L. G. Straub, Director

St. Anthony Falls Hydraulic Laboratory

University of Minnesota

Minneapolis 14, Minnesota

Attn: Mr. J. N. Wetzel

Professor B. Silberman

Professor J. J. Foody

Engineering Department

New York State University Maritime College

Fort Schulyer, New York

New York University

Institute of Mathematical Sciences

New York 3, New York

Attn: Professor J. Keller

Professor J. J. Stoker

The Johns Hopkins University

Department of Mechanical Engineering

Baltimore 18, Maryland

Attn: Professor S. Corrsin

Professor O. M. Phillips

Massachusetts Institute of Technology

Department of Naval Architecture and

Marine Engineering

Cambridge 39, Massachusetts

Attn: Professor M. A. Abkowitz, Head

Dr. G. F. Wislicenus

Pennsylvania State University

University Park, Pennsylvania

Attn: Dr. M. Sevik

Professor R. C. DiPrima

Department of Mathematics

Rensselaer Polytechnic Institute

Troy, New York

Director

Woods Hole Oceanographic Institute
25 Waverly Place 
Stevens Institute of Technology

Davidson Laboratory

Castle Point Station

Hoboken, New Jersey

Attn: Mr。D. Savitsky

Mr. J. P. Breslin

Mr. C. J. Henry

Mr. S. Tsakonas

Webb Institute of Naval Architecture

Crescent Beach Road

Glen Cove, New York

Attn: Professor E. V. Lewis

Technical Library

Executive Director

Air Force Office of Scientific Research

Washington 25, D. C.

Attn: Mechanics Branch

Commander

Wright Air Development Division

Aircraft Laboratory

Wright-Pattern Air Force Base, Ohio

Attn: Mr. W. Mykytow, Dynamics Branch

Cornell Aeronautical Laboratory

4455 Genesee Street

Buffalo, New York

Mr. R. White

Massachusetts Institute of Technology

Fluid Dynamics Research Laboratory

Cambridge 39, Massachusetts

Attn: Professor H. Ashley

Professor M. Landahl

Professor J. Dugundji
Attn: Mr. W. Targoff

Shipsmodelltanken

Trondheim, Norway

Attn: Professor J. K. Lunde

Versuchsanstalt fur Wasserbau and Schiffbau

Schleuseninsel im Tiergarten

Berlin, Germany

Attn: Dr. S. Schuster, Director

Dr. Grosse

Technis che Hoges chool

Institut voor Toegepaste Wiskunde

Julianalaan 132

Delft, Netherlands

Attn: Professor R. Timman

Bureau D'Analyse et de Recherche Appliquees

47 Avenue Victor Bresson

Is sy-Les-Moulineaux

Seine, France

Attn: Professor Siestrunck

Netherlands Ship Model Basin

Wageningen, The Netherlands

Attn: Dr. Ir. J. D. vanManen

National Physical Laboratory

Teddington, Middlesex, England

Attn: Mr. A. Silverleaf, Superintendent Ship Division

Head, Aerodynamics Division

Head, Aerodynamics Department

Royal Aircraft Establishment

Farnborough, Hants, England

Attn: Mr. M. O. W. Wolfe

Dr. S. F. Hoerner

148 Busteed Drive

Midland Park, New Jersey

Bramfelder Strasse 164

Hamburg 33, Germany

Attn: Dr. H. Schwanecke

Dr. H. W. Lerbs

Institut fur Schiftbau der

Universitat Hamburg

Berliner Tor 21

Hamburg 1, Germany

Attn: Prof. G. P. Weinblum,

Transportation Technical Research Institute

Boeing Airplane Company

Seattle Division

Seattle, Washington

Attn: Mr. M. J. Turner

Electric Boat Division

General Dynamics Corporation

Groton, Connecticut

Attn: Mr. Robert McCandliss

1-1057, Mejiro-Cho, Toshima-Ku

Tokyo, Japan

General Applied Sciences Labs., Inc.

Merrick and Stewart Avenues

Westbury, Long Island, New York

Max-Planck Institut fur Stromungsforschung

Bottingerstrasse $6 / 8$

Gottingen, Germany

Attn: Dr. H. Reichardt

Gibbs and Cox, Inc.

21 West Street

New York, New York

Hydro-og Aerodynamisk Laboratorium

Lyngby, Denmark

Attn: Professor Carl Prohaska
Lockheed Aircraft Corporation

Missiles and Space Division

Palo Alto, California

Attn: R. W. Kermeen 
Grumman Aircraft Engineering Corp. Bethpage, Long Island, New York

Attn: Mr. E. Baird Mr. E. Bower Mr. W. P. Carl

Midwest Research Institute 425 Volker Blvd.

Kansas City 10, Missouri

Attn: Mr. Zeydel

Director, Department of Mechanical

Sciences

Southwest Research Institute

8500 Culebra Road

San Antonio 6, Texas

Attn: Dr. H. N. Abramson

Mr. G. Ransleben

Editor, Applied Mechanics

Review

Convair

A Division of General Dynamics

San Diego, California

Attn: Mr. R. H. Oversmith

$\mathrm{Mr}$. H. T. Brooke

Hughes Tool Company

Aircraft Division

Culver City, California

Attn: Mr. M. S. Harned

Hydronautics, Incorporated

Pindell School Road

Howard County

Laurel, Maryland

Attn: Mr. Phillip Eisenberg

Rand Development Corporation

13600 Deise Avenue

Cleveland 10, Ohio

Attn: Dr. A. S. Iberall

U. S. Rubber Company

Research and Development Department

Wayne, New Jersey

Attn: Mr. L. M. White

Technical Research Group, Inc.

Route 110

Melville, New York, 11749

Attn: Mr. Jack Kotik

Mr. C. Wigley

Flat 102

6-9 Charterhouse Square

London, E. C. 1, England

AVCO Corporation

Lycoming Division

1701 K Street, N. W.

Apt. No. 904

Washington, D. C.

Attn: Mr. T. A. Duncan
Mr. J. G. Baker

Baker Manufacturing Company

Evansville, Wisconsin

Curtiss - Wright Corporation Research

Division

Turbomachinery Division

Quehanna, Pennsylvania

Attn: Mr. George H. Pedersen

Dr. Blaine R. Parkin

AiResearch Manufacturing Corporation 9851-9951 Sepulveda Boulevard

Los Angeles 45, California

The Boeing Company

Aero-Space Division

Seattle 24, Washington

Attn: Mr. R. E. Bateman

(Internal Mail Station 46-74)

Lockheed Aircraft Corporation

California Division

Hydrodynamics Research

Burbank, California

Attn: Mr. Bill East

National Research Council

Montreal Road

Ottawa 2, Canada

Attn: Mr. E. S. Turner

The Rand Corporation

1700 Main.Street

Santa Monica, California

Attn: Technical Library

Stanford University

Department of Civil Engineering

Stanford, California

Attn: Dr. Byrne Perry

Dr. E. Y. Hsu

Dr. Hirsh Cohen

IBM Research Center

P. O. Box 218

Yorktown Heights, New York

Mr. David Wellinger

Hydrofoil Projects

Radio Corporation of America

Burlington, Massachusetts

Food Machinery Corporation

P. O. Box 367

San Jose, California

Attn: Mr. G. Tedrew

Dr. T. R. Goodman

Oceanics, Inc.

Technical Industrial Park

Plainview, Long Island, New York 
Professor Brunelle

Department of Aeronautical Engineering

Princeton University

Princeton, New Jersey

Commanding Officer

Office of Naval Research Branch Office

230 N. ivichigan Avenue,

Chicago 1, Illinois

University of Colorado

Aerospace Engineering Sciences

Boulder, Colorado

Attn: Prof. M. S. Uberoi

The Pennsylvania State University

Dept. of Aeronautical Engineering

Ordnance Research Laboratory

P. O. Box 30

State College, Pennsylvania

Attn: Professor J. William Holl

Institut fur Schiffbau der Universitat Hamburg

Lammersieth 90

2 Hamburg 33, Germany

Attn: Dr. O. Grim

Technische Hogeschool

Laboratorium voor Scheepsbounkunde

Mekelweg 2, Delft, Netherlands

Attn: Professor Ir. J. Gerritsma 